\title{
The effects of strategy and market orientation on the performance of Vietnamese startups
}

\author{
Hoang Van Hai ${ }^{a}$, Nguyen Duc Xuan ${ }^{b^{*}}$, Truong Duc Thao ${ }^{c}$ and Pham Thi Thu Hien \\ ${ }^{a} V N U$ - University of Economics and Business, Vietnam \\ ${ }^{b}$ Hanoi Financial and Banking University, Vietnam \\ ${ }^{c}$ Dai Nam University, Vietnam \\ C H R O N I C L E \\ Article history: \\ Received: July 10, 2020 \\ Received in revised format: \\ October 182020 \\ Accepted: November 4, 2020 \\ Available online: \\ November 4, 2020 \\ Keywords: \\ Strategy \\ Business strategy \\ Market orientation \\ Vietnamese startup enterprise

\section{A B S T R A C T} \\ This study is based on the results of a survey of 518 start-ups in Vietnam during the period of \\ establishment from 2016 to 2018. Data collection lasted from November 2019 to May 2020, inter- \\ rupted by Covid-19 translation and collected data were processed on SPSS20 and AMOS24 soft- \\ ware, model estimation and hypothesis testing using linear structural equations (SEM). The re- \\ search results show that business strategy and market-oriented factors had positive impacts on the \\ performance of Vietnamese startups. However, no regulatory relationship of business strategy has \\ been found that affects the impact relationship of market orientation with business performance. In \\ addition, the study also found that, in current context, startups pursuing defensive strategies have \\ more success than firms pursuing pioneering strategies and startups in the field. Trade / services \\ are more likely to succeed than in agriculture and industry.
}

(C) 2021 by the authors; licensee Growing Science, Canada

\section{Introduction}

According to the General Statistics Office of Vietnam, in 2017 there were a total of 561,064 enterprises, of which more than $90 \%$ were SMEs, positively impacting the startup movement launched by the Government of Vietnam, among 5 in the first month of 2018, there were 52,322 newly established enterprises, with the registered capital of 516,859 billion VND, the number of enterprises returning to operation was 13,267 enterprises. This is a great effort of the business community and society; however, the number of enterprises that registered to suspend operations for a definite period was 15,974 and enterprises that suspended operations without registration or awaiting dissolution were 17,425 enterprises (National Business Registration Portal). It can be seen that the number of newly established businesses is quite high, but the number of businesses that fail is not small. So, what makes the success or failure of Vietnamese startups? In fact, Vietnamese startups often start from having a business idea without careful preparation of strategic thinking, clear market orientation, leading to difficulties in determining direction and building a competitive advantage when starting the business. Therefore, this study is conducted to examine the impact of business strategy and market orientation on the success or failure of Vietnamese startups.

\section{Literature Reviews}

\subsubsection{Important concepts}

\subsubsection{Business strategy}

Corporate strategy is divided into 3 levels, including firm-level strategy, business strategy and functional level strategy (Beard \& Dess, 1981) in which, business strategy is determined by changes in business characteristics related to success or failure to compete with competitors in a certain industry (Beard \& Dess, 1981). Business strategy includes more general processes,

* Corresponding author.

E-mail address: ducxuancnttb@gmail.com (N.D. Xuan) 
plans, and goals, and covers functional strategy (Williams et al., 1995). Business strategy has long been proven by studies to demonstrate its influence on firm's performance (Beard \& Dess, 1981). Business strategy is also expected to help enterprises increase the competitive position of products and services of a business unit, an enterprise in a specific industry or segment in which the business or business unit is that business is competing (Dina \& Cahyandito, 2018). This is in line with the definition of a business strategy above, which emphasizes a difference that creates a competitive advantage or disadvantage among competitors in a particular industry (Beard \& Dess, 1981).

Up to now, researchers have given many different perspectives on business strategy. According to these researchers, business strategy can be an organization's effort to help its business compete better than similar competitors in the industry. The strategy aligns the organization's environmental adaptation planning models, using available resources through which the organization seeks to achieve its strategic goals, often with a sustainable competitive advantage. firm. Although there are many views on business strategy, up to now the concepts and how to business strategies classification of Miles et al. in 1978 are most widely recognized.

According to Miles et al. (1978), each business will tend to adopt a different business strategy corresponding to its position. This creates four types of businesses, namely: pioneers; cautious people; defenders and reactors (Raymond \& Croteau, 2009). In it, a pioneer is defined as a business in which they are almost continually searching for market opportunities and frequently testing potential responses to emerging environmental trends (Miles et al., 1978). As a result, these organizations are often change-makers and are uncertain about their opponents (Miles et al., 1978; Menguc \& Auh, 2008). A company is considered to be a pioneer if it regularly introduces new products as well as looks for possibilities in new markets (Raymond \& Croteau, 2009). On the contrary, defenders are organizations with a narrow range of markets, so they rarely make major adjustments to the technology, production methods or structure of the business. Instead, they devote primary attention to improving the efficiency of their current operations (Miles \& Snow, 1978; Menguc \& Auh, 2008). These firms, for the most part, are often well aware of their competitors, because they are less likely to change their serving markets, and competitor ambiguity usually occurs only when new competitors enter the market. Next is the cautious, businesses that apply this strategy often accept second place, after the pioneer, they are willing to trade big business opportunities with the position of the leader to decrease. risk mitigation (Raymond \& Croteau, 2009; Miles \& Snow, 1978). Businesses that follow this strategy can gain more profits by not having to invest in initial research costs. They often accept the position of second or even 3rd person and seek to consolidate this position, not develop to a higher position. The final type is the responders. According to Miles et al. (1978), that will often lead to failure. Firms that follow are likely not having specific strategy (Miles et al., 1978; Raymond and Croteau, 2009), who react means business operations. Their changes depend on the actual situation, there is absolutely no consistency in action.

\subsubsection{Market orientation}

Market orientation is part of a manufacturing strategy that has been shown to influence business performance (Williams et al., 1995). The concept of market orientation is derived from a philosophy in management that is the concept of marketing. This philosophy is the foundation of Drucker's marketing principles in 1954 (Raaij \& Stoelhorst, 2008). In a modern business strategy, market orientation has an increasingly important role in providing businesses with continuous information about the market and its competitors. Businesses will rely on this information to create outstanding customer value (Slater and Narver, 1995). In other words, businesses will respond to the information received from the market to offer the best products for customers and outperform their competitors (Dina \& Cahyandito, 2018). From these views, many studies have shown that market orientation positively affects market performance (Slater \& Narver, 1995). There have been many researchers giving their views on market orientation in their research (Raaij \& Stoelhorst, 2008). According to these researchers, market orientation is viewed from an enterprise-wide perspective, which is the understanding related to the current and future needs of customers, disseminating this understanding between departments and within the whole organization (Kohli \& Jaworski, 1990). Market orientation can also be understood as the most efficient and effective business culture, taking the necessary actions to create outstanding value for customers (Slater \& Narver, 1995). Furthermore, according to Day (1994), market orientation demonstrates superior skills in understanding and satisfying customers (Day, 1994). Thus, with the above views, market orientation has two main approaches. The first is the behavioral approach, which market-oriented is viewed as a set of activities to increase customer satisfaction (Gaur et al., 2011). The second is the cultural approach, which market-oriented, emphasizes the diffusion of values and beliefs throughout the enterprise to put the interests of the customers first (Slater \& Narver, 1995). Although there are two different approaches, researchers agree that the customer is the key factor of market orientation (Dina \& Cahyandito, 2018). And market orientation is composed of 3 main components, including: customer orientation, competitor orientation and cross-functional collaboration (Slater \& Narver, 1995; Dina \& Cahyandito, 2018), level. The firm's market orientation's level will be calculated by the simple average of these 3 components.

\subsubsection{Performance results}

Business performance is often measured based on two main groups of criteria: financial and non-financial. Business performance in terms of non-financial factors is often measured through criteria such as market share, sales growth, quality of products and services, customer retention rate, etc. Meanwhile, business performance from a financial perspective is often 
measured by the rate of return on assets, rate of return on investment, etc. (Chung et al, 2012). Performance is often evaluated based on the firm's growth compared to the past or on correlation with competitors (Chung et al., 2012). However, with the characteristics of enterprises as a start-up, comparison with competitor businesses is relatively difficult, so the results are often assessed against the expectations of the innovators. (Chung et al., 2012).

\subsubsection{Factors affecting the performance of startups}

\subsubsection{Market orientation}

Market orientation, as noted above, has a positive effect on performance, but the degree of influence also depends on entrepreneurship (Slater \& Narver, 1995), size of the company, type of companies that produce or provide services, companies that manufacture industrial or consumer goods, or for-profit or non-profit companies, etc. (Raaij \& Stoelhorst, 2008). Although the degree of impact of market orientation on corporate performance varies, studies show a positive effect of market orientation on performance in all respects. such as: financial results, market share and profit. From the above analysis, the study suggests:

H1a: Customer orientation positively affects the results of startup businesses.

$\mathrm{H} 1 \mathrm{~b}$ : Competitor orientation positively affects the results of startup businesses.

H1c: The closer the cross-functional collaboration among departments in the business is geared towards the market, the better the performance of a startup business.

\subsubsection{Business strategy}

Business strategy is one of the most fundamental factors affecting operating results and consequently the existence of businesses, businesses that do not have a coherent and consistent business strategy will often fail to achieve the desired results and quickly fail (Miles \& Snow, 1978). According to Miles et al. (1978), the four types of businesses correspond to four types of strategies, including: pioneers, cautious people, defensive people, reactors. Businesses that respond to responders often fail quickly. At the same time, cautious people are neutral in the other three strategies (Miles \& Snow, 1978). Therefore, in this study, we will not consider the effect of the cautious and the reactors, but the pioneers and the defenders on business performance. Although these business strategies will bring different results at different times, in other words, each business strategy can bring successes for businesses if applied with right conditions. However, in the research's context of start-ups, when the products of new businesses are released to the market, there is no certain stability. Especially in the context that startups do not have a deep understanding of the market, a defensive business strategy is easy to push businesses to poor performance results and fail quickly, when the businesses that adopt the defensive strategy are often passive with market demands. In contrast, the startups apply pioneers business strategy may not really understand the market at first, but with the nature of the enterprise always looking for new product development, they will often grasp the needs of the market and conduct business activities more smoothly and can get better results. From the above analysis, the study hypothesizes:

$\mathrm{H}_{2}$ : Startups applying a pioneer business strategy will have better performance than startups that apply defensive business strategies.

\subsubsection{The regulatory influence of business strategy on the influence of market orientation on startup performance.}

Slater and Narver (1995) claim that market orientation can achieve maximum results when it is operated in an organizational environment with the right structures, processes and conditions (Slater \& Narver, 1995). Therefore, it is important for any business to create the right environment that maximizes the organization's capture of information to create outstanding customer value, for capturing and generating prices. Value for customers to outperform and outperform competitors is the only source of sustainable competition (Slater \& Narver, 1995). In this research framework, similar to the above section, the author only considers the influence of the pioneer and defensive person trading strategy on market orientation. Businesses that adopt pioneering business strategies, as Miles et al. (1978) define as businesses constantly seek new market opportunities, and test new products according to new market trends. floating (Miles et al., 1978; Raymond \& Croteau, 2009). Therefore, naturally, businesses that adopt a pioneering business strategy will create conditions for customer-oriented behaviors to be applied. In contrast, firms that adopt a defensive business strategy are often organizations with a narrow market scope, so they rarely make major adjustments to their technology, production method or business structure. Karma. Instead, they are devoted to improving the performance of their current market operations (Raymond \& Croteau, 2009). Therefore, to a certain extent, a defensive person business strategy will not facilitate market-oriented development, since these businesses have little demand in understanding customers. Although, previous studies have not completely mentioned the regulatory ability of business strategy to the impact of market orientation on operating results. However, as analyzed above, the author hopes that there is a regulation among business strategy with the representative of the pioneers and defenders which influence the market orientation. Activities, therefore, the study hypotheses: 
H3a: The pioneer's strategy affects the relationship between customer orientation and startup business more than the defenders.

$\mathrm{H} 3 \mathrm{~b}$ : The pioneer's strategy affects the relationship between competitor orientation and the results of the startup business more than the defenders.

$\mathrm{H} 3 \mathrm{c}:$ The pioneer's strategy affects the relationship between the cross-functional collaboration to the results of the startup business more than the business strategy of the defender.

\section{Model and data}

\subsection{Model, hypothesis and research scales}

\section{Research models}

From the results of the research overview and theoretical basis above, we generalize the research model to describe the relationship of the impact of business strategy and market orientation on the performance of startups. Vietnamese industry is as follows:

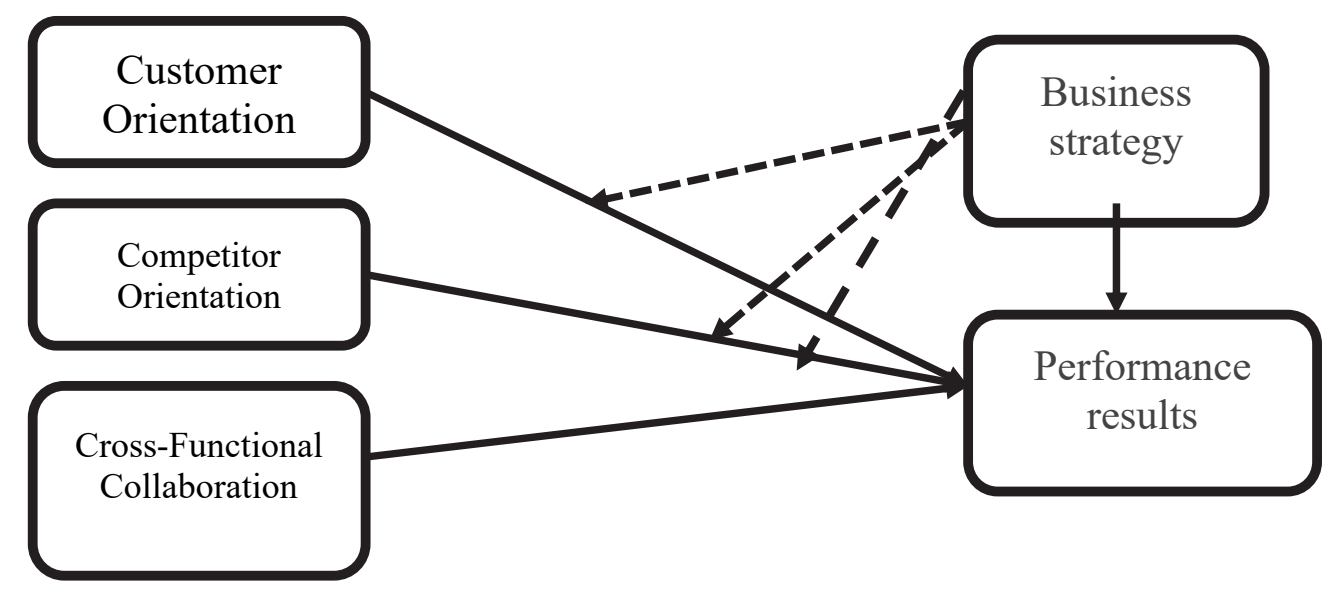

Fig. 1. Research model of the impact of business strategy, market orientation on business performance

Source: Self-synthesized research team

\section{Research hypotheses}

From the above analysis and arguments and based on the research model, we propose the following research hypotheses:

$\mathrm{H}_{1 \mathrm{a}}:$ Customer orientation positively affects the results of startup businesses

$\mathrm{H}_{1 \mathrm{~b}}$ : Competitor orientation positively affects the results of startup businesses

$\mathrm{H}_{1 \mathrm{c}}$ : The closer the cross-functional collaboration among departments in the business is geared towards the market, the better the performance of a startup business.

$\mathrm{H}_{2}$ : Startups applying a pioneer business strategy will have better performance than startups that apply defensive business strategies.

$\mathrm{H}_{3 \mathrm{a}}$ : Business strategy pioneer affects the relationship between customer orientation to the results of the startup business more than the business strategy of defenders.

$\mathrm{H}_{3 \mathrm{~b}}$ : Business strategy pioneer affects the relationship between competitor orientation to the results of the startup business more than the business strategy of defenders.

$\mathrm{H}_{3 \mathrm{c}}$ : Business strategy pioneers influence the relationship between the cross-functional collaboration orientation to the results of the startup business more than the business strategy of the defender. 
In this study, the factors of market orientation, business strategy and performance are the factors that many authors have studied in many previous studies with the research toolset as scales. The measure has been used stably across many different cultural contexts and types of businesses. Therefore, in this study, the author will reuse these widely used scales. The scales all use the 5 Likert scale, with 1 being strongly disagree and 5 being strongly agreeing. The scales used in the study include:

\section{1) Scale of market orientation}

This scale was translated and edited by the author from the scale of Narver and Slater (1990) to suit the research conditions of this study. Specifically, this scale includes 15 observed variables, in which the component scales are customer oriented including 5 observed variables, the competitive orientation scale includes 6 observed variables and the cross-functional collaboration scale includes 4 observed variables. The scale details are shown in the table:

\begin{tabular}{|c|c|c|}
\hline The scale & Observed variables & Author \\
\hline \multirow{5}{*}{$\begin{array}{l}\text { Customer } \\
\text { oriented }\end{array}$} & My business is constantly trying to discover more customers' needs that they do not even know & \multirow{5}{*}{$\begin{array}{c}\text { Narver } \\
\text { and } \\
\text { Slater, } \\
1990\end{array}$} \\
\hline & My business predicts what customers may need and recommends new products and services that my business can offer them. & \\
\hline & $\begin{array}{l}\text { My business always tries to innovate its business based on complaints to meet the needs of customers even when my business } \\
\text { recognizes the possibility of risk. }\end{array}$ & \\
\hline & My business often thinks about the benefits that customers get from the products and services of my business & \\
\hline & $\begin{array}{l}\text { My business communicates closely with potential customers and tries to recognize their needs for months or even years before most } \\
\text { of the competition. }\end{array}$ & \\
\hline \multirow{6}{*}{$\begin{array}{l}\text { Competitive } \\
\text { orientation }\end{array}$} & My business always collects and is interested in the activities of competitors & \multirow{6}{*}{$\begin{array}{c}\text { Narver } \\
\text { and } \\
\text { Slater, } \\
1990\end{array}$} \\
\hline & My business often judges the competitor's goals & \\
\hline & My business always monitors the business performance of major competitors & \\
\hline & My business often identifies the reasons that our main competitors have been successful or failed & \\
\hline & My business often assesses the strengths and weaknesses of competitors. & \\
\hline & My business often targets target customers whose business has a competitive advantage & \\
\hline \multirow{4}{*}{$\begin{array}{l}\text { Cross- } \\
\text { functional } \\
\text { collaboration }\end{array}$} & We regularly visit current and future customers & \multirow{4}{*}{$\begin{array}{c}\text { Narver } \\
\text { and } \\
\text { Slater, } \\
1990\end{array}$} \\
\hline & We often freely discuss our customer service successes and failures with our partners. & \\
\hline & Everyone in our supply chain understands how they can contribute to creating customer value & \\
\hline & We always share resources with other members of the distribution channel & \\
\hline
\end{tabular}

\section{2) Scale business strategy}

To determine which business strategy a business is using, researchers often use four questions with CEOs to find them and find out which question best suits their business strategy (Raymond and Croteau, 2009). In this study, the author uses 2 questions about pioneer and defender from 4 questions about business strategies of Raymond and Croteau (2009). In the questionnaire, the author added a "different" scenario for businesses that do not apply any of the two business strategies of pioneers and defenders.

\begin{tabular}{llll}
\hline No. & The scale & Observed variables & Author \\
\hline 4 & Pioneers & $\begin{array}{l}\text { I constantly innovate and regularly launch new products / services } \\
\text { My first goal is to maintain my current market share with existing products / services by lowering prices or }\end{array}$ & $\begin{array}{l}\text { Raymond and } \\
\text { Croteau, 2009 }\end{array}$ \\
\hline
\end{tabular}

\section{3) Scale of business results}

To measure the performance results, the author used the scale in the study of Chung et al. (2012) and edited in accordance with the study. This scale includes 6 observed variables (Chung et al., 2012), specifically:

\begin{tabular}{lll}
\hline No. The scale & Observed variables \\
\hline & $\begin{array}{l}\text { The rate of profit of the business is higher than expected } \\
\text { Enterprise's sales growth was higher than expected } \\
\text { Customers are more satisfied with its products / services than expected }\end{array}$ \\
\hline & $\begin{array}{l}\text { Performance } \\
\text { results }\end{array}$ & $\begin{array}{l}\text { A high percentage of long-term customers transacting with the company was higher than expected } \\
\text { The company has a higher rate of successful new products in the market than expected } \\
\text { The company's rate of return on investment was higher than expected. }\end{array}$ \\
\hline
\end{tabular}




\subsection{Data}

The research mainly uses primary data based on surveys of 518 Vietnamese start-ups on business strategy, market orientation and operating results. Sample size is calculated according to Hair et al. (1998) sampling formula, accordingly, with 23 questions on strategy, market orientation and operating results of Vietnamese startups, the minimum number of survey samples needed is 115 or 230 valid votes. The businesses surveyed included 138 industrial startups, 175 agriculture businesses, 205 trade / service firms, and were surveyed in the North, the Central and the South of Vietnam. Thus, with 518 valid survey forms used in the study, the sample size of the study satisfies the conditions to analyze discovery factors EFA, CFA confirmatory factor analysis, and estimate the model by linear structure and highly representative SEM to ensure reliable research results. The data test results show that, after two EFA analysis with Principal axis factoring method with Promax rotation and the stop when extracting elements with eigenvalue of the matrix (eigenvalue) equal to 1 is used. used for factor analysis with 23 observed variables, the coefficient KMO reached 0.906 with the value of Sig. $=0.000$ and Eigenvalues value reached 78,604 at the stop factor reached 1,333. The rotation matrix results also show that the scales of the study converge on 03 marketoriented factors and 01 operating result factor consistent with the proposed theoretical research model. The results of testing the reliability of the concepts and research scales show that Cronbach's Alpha coefficients of all factors reach a value greater than 0.7 , so the scales used in the study are appropriate. The results of the factor analysis confirmed CFA for these scales has 179 degrees of freedom $(\mathrm{df}=179)$. CFA test results show that the model is compatible with the research data set: Chi-square $=647.308(\mathrm{p}=0.000) ; \mathrm{cmin} / \mathrm{df}=3.616$; GFI $=0.902 ; \mathrm{TLI}=0.947$; CFI $=0.955 ;$ and $\mathrm{RMSEA}=0.071$. The normalized weights of the observed variables are greater than 0.5 and the standardized weights of the variables are statistically significant, thus confirming the convergence of the scales. Correlation coefficients of concepts are all less than one unit, so the concepts gain discriminant validity. The measurement model is suitable for the research data set, there is no correlation between the measurement errors, so the uniqueness is achieved. Thus, the research data set satisfies the electrical conditions to include in the test of the linear structure model of the relationship of business strategy and market orientation to the performance of Vietnamese startups.

\section{Results and discussion}

\subsection{Model testing results with linear structural equations (SEM)}

The results of the critical model test have 247 degrees of freedom $(\mathrm{df}=247)$. SEM test results show that the model achieved the compatibility with the research data set with the values, Chi-square $=760.798(\mathrm{p}=0.000) ; \mathrm{cmin} / \mathrm{df}=3.080 ; \mathrm{GFI}=0.902$; $\mathrm{TLI}=0.944 ; \mathrm{CFI}=0.954$; and RMSEA $=0.063$. The impact of the business strategy, market orientation on the performance of Vietnamese startups has the model's estimated results for R $2=0.709$, which means $70.9 \%$ of the change the performance of Vietnamese start-ups is influenced by the business strategy and market orientation of the business. In which, "Customer Orientation" has the strongest impact on "operating results of Vietnamese startups" with a standardized Beta coefficient of 0.512 and at the statistical significance of $99 \%$; followed by "Competitor Orientation" with standardized Beta coefficient of 0.170 and at statistical significance of $99 \%$; third is "Business Strategy" with standardized Beta coefficient of 0.146 and at the statistical significance of $99 \%$; the fourth is "Cross-functional collaboration" with standardized Beta coefficient of 0.143 and at the statistical significance of $99 \%$. On the other hand, when considering the impact of factors such as seniority, area of activity and region of activity on the performance of Vietnamese startups or not, the estimation results show that, (1) There is no statistically significant impact of seniority and region on the performance of Vietnamese startups; (2) There is a statistically significant difference that affects the operating results of Vietnamese startups with a standardized Beta coefficient of 0.332 and at the statistical significance of $99 \%$, meaning Trade / service startups have outperformed agricultural and industrial startups. Estimated results of the main parameters in the theoretical model are presented in the table below. Estimated results show that all hypotheses H1a, H1b, H1c and H2 are accepted with statistical significance of over $99 \%$. Specifically:

Table 1

Estimation results of the standardized model (SEM)

\begin{tabular}{|c|c|c|c|c|c|c|}
\hline No. & Relationship between concepts & Non-standardized estimates & Standardized estimates & Standard deviation & Value $(\mathrm{t})$ & Value (p) \\
\hline \multicolumn{7}{|c|}{ R2 of Vietnamese enterprise product innovation $=0.709$} \\
\hline 1 & $\mathrm{KQHD} \leftarrow \mathrm{DHDT}$ & 0.154 & 0.17 & 0.029 & 5.362 & 0 \\
\hline 2 & $\mathrm{KQHD} \leftarrow \mathrm{DHKH}$ & 0.513 & 0.512 & 0.04 & 12.74 & 0 \\
\hline 3 & $\mathrm{KQHD} \leftarrow \mathrm{DHPH}$ & 0.173 & 0.143 & 0.037 & 4.727 & 0 \\
\hline 4 & $\mathrm{KQHD} \leftarrow$ Tnien & 0.045 & 0.038 & 0.04 & 1.131 & 0.258 \\
\hline 5 & $\mathrm{KQHD} \leftarrow$ Lvuc & 0.385 & 0.332 & 0.051 & 7.573 & 0 \\
\hline 6 & $\mathrm{KQHD} \leftarrow \mathrm{CLKD}$ & 0.273 & 0.146 & 0.052 & 5.273 & 0 \\
\hline 7 & $\mathrm{KQHD} \leftarrow$ Vmien & -0.059 & -0.053 & 0.039 & -1.507 & 0.132 \\
\hline
\end{tabular}

(Source: Results of data processing on Amos24)

The results of estimating the volatile and immutable models, testing the regulatory relationship of business strategy on the impact of market orientation on the performance of Vietnamese startups show results is Chidist result $=0.522361(>0.5)$, 
thus concluding, no difference in relationship has been found in the positive impact of the pioneer business strategy compared to the business strategy of the defender on the impact of market orientation to the performance of Vietnamese startups. Therefore, hypotheses $\mathrm{H} 3 \mathrm{a}, \mathrm{H} 3 \mathrm{~b}$, and $\mathrm{H} 3 \mathrm{c}$ are rejected. Specifically:

\section{Table 2}

Results of the test of the throttling of business strategies on the impact of market orientation on the performance of Vietnamese startups

\begin{tabular}{|c|c|c|}
\hline & Chi - Square & df \\
\hline Variable model & 966.363 & 358 \\
\hline Immutable model & 968.612 & 361 \\
\hline Brand & 2.249 & 3 \\
\hline Chidist & 0.522361 & \\
\hline
\end{tabular}

Source: Calculated from the results of data analysis on Amos24

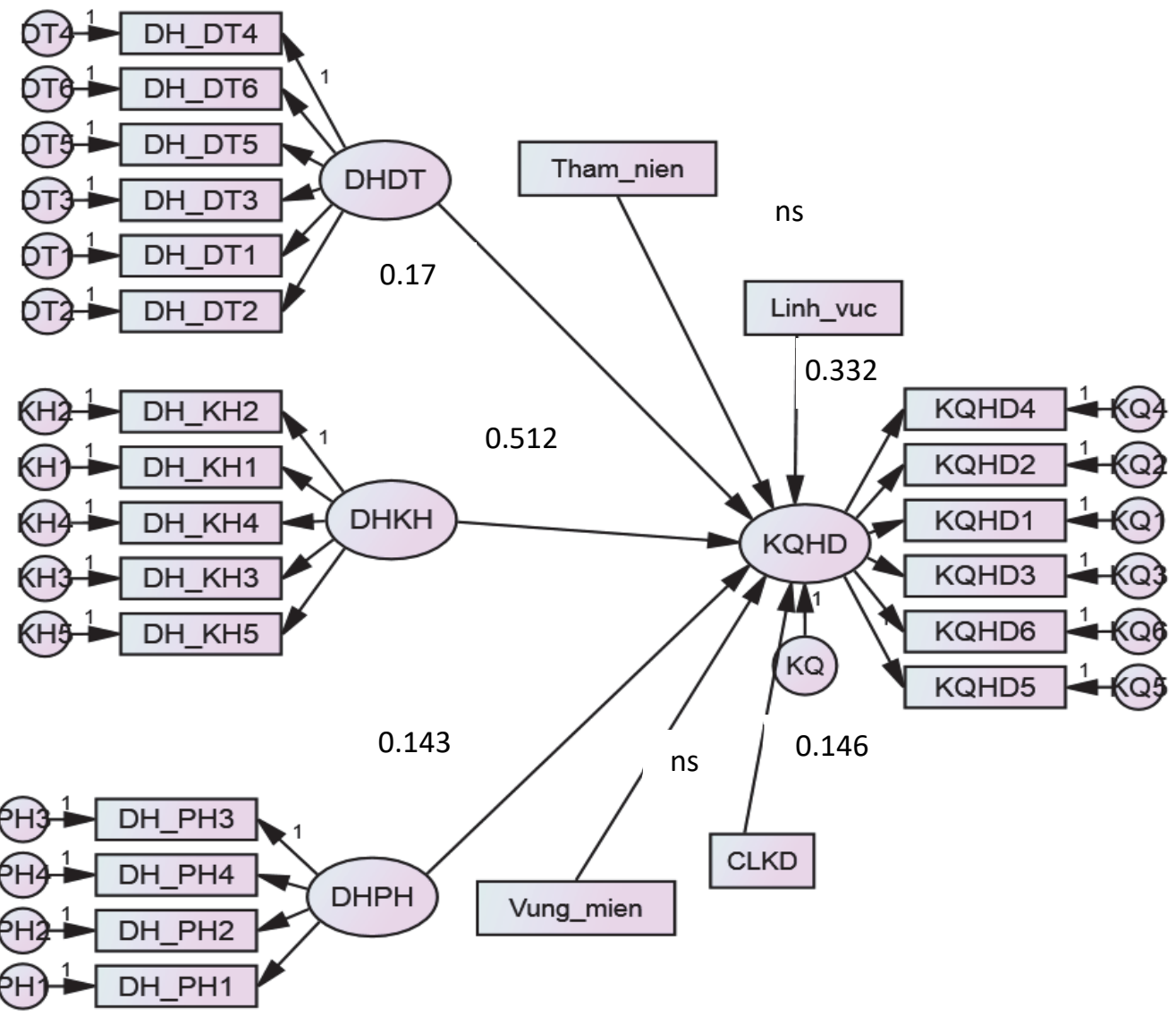

(Source: Calculated results from linear structure model)

Fig. 2. Result of testing theoretical model

\subsection{Finding Discussion}

From the estimation results of the research subject, we give the following comments:

First, Market orientation has a positive impact on the performance of Vietnamese startups, in which the strongest impact is customer orientation with a standardized Beta of 0.512 and at significance over $99 \%\left(\mathrm{P}_{-}\right.$value $\left.=0.000\right)$; second is competitor orientation with standardized Beta of 0.170 and over $99 \%$ significance level $(\mathrm{P}$ value $=0.000)$; and the third is the crossfunctional collaboration with standardized Beta of 0.143 and at significance level above $99 \%(P$ value $=0.000)$. This result is consistent with the study of Gonçalves Filho et al. (2012) on a sample of 1,552 SMEs (including family and private enterprises) in Brazil, the results confirm, market orientation has a positive impact on SME performance in Brazil with a standardized beta of 0.28 (Gonçalves Filho et al., 2012). While another study by Ho et al. (2017) on the impact of market orientation 
on the performance of 190 enterprises in the agricultural value chain in Vietnam (Ho et al., 2017). The study results do not show a direct influence between market orientation and the performance of business enterprises in the value chain of the agricultural sector in Vietnam. However, market orientation influences business innovation and indirectly affects the performance of these businesses. Thus, for Vietnamese start-ups, the customer-centric market orientation, regular research on customer needs will help meet the needs of the market and is a very decisive factor. great success of startups.

Second, Business strategy has a positive impact on the performance of Vietnamese start-ups, in which businesses pursuing defense strategies have better performance than pioneering businesses. when the Beta (0.273) and standardized Beta (0.146) were both positive and quite high. This result is in conflict with the research results of Olson et al. (2005) when the study on a sample of 63 enterprises applying the pioneer strategy, 43 enterprises applying the strategy of defenders by cost. Low, 63 firms applying defense strategy with differentiation in the US showed that the defense strategy towards product differentiation will have better results than the pioneering strategy, and the pioneering strategy will work results low cost defense strategy. For startups, creativity is always on top, so the pioneering strategies will prevail to have better performance than the defense strategy. However, in the startup scene in Vietnam, startups are often small-scale with little capital, so it is difficult for these businesses to pursue pioneering strategies, instead based on defense strategies. on creating novelty for existing products or changing the way of distribution, lowering the cost of existing products will bring success to the startup.

Third, the commercial / service startups outperform the agricultural and industrial startups. This is relatively easy to understand in the context of start-ups in Vietnam, where investment capital for industrial and agricultural projects is often large and the payback time and profitability are slower than service businesses. with a lower investment capital.

Fourth, no difference has been found in the relationship of the positive impact of the pioneer business strategy compared to the defensive business strategy on the impact of market orientation on the performance of the business. Vietnamese start-ups. This result also contradicts the research results of Olson et al. (2005), when saying that, with enterprises applying the pioneer strategy, the more customers-oriented businesses, the more their performance results. high. Meanwhile, for businesses that adopt low-cost defense strategies, there is no influence of customer orientation on operating results. And finally, with businesses that apply a defense strategy by differentiation, customer orientation has the strongest impact and is positive on operating results. As for competition orientation (one of the components of market orientation). The result is that the difference in the degree of regulation of the business strategy affects the effect of market orientation on operating results. Specifically, with a pioneering company with a higher competitive orientation, the poorer performance will be, on the contrary, businesses that adopt a low-cost defense strategy will have better performance when they have. higher level of competitive orientation. And finally, firms pursuing a defensive business strategy by differentiation do not note the effect of the direction of competition on their performance.

\subsection{Proposed solutions}

From the above research results, we propose a number of suggestions for solutions to guide the success of Vietnamese startups as follows:

First, Vietnamese startups must clearly define their goals and specific strategies right from the time they build their startup projects.

Second, startup ideas need to focus on meeting customer needs as much as possible, being customer-centric, regularly researching and responding to customer needs rather than researching competitors.

Third, the low-cost and differentiated defense strategies bring immediate success to Vietnamese startups rather than pioneering. However, in the long run, in order to survive and continue to be successful, Vietnamese startups need to focus on pursuing a pioneering strategy or defending differentiation, for one of the key elements of entrepreneurship. product creation and optimized solutions for customers.

Fourth, Vietnamese startups need to focus more on the areas of commerce / services than on manufacturing because these sectors are suitable for capital size as well as the specifics of the agricultural economy. of Vietnam.

Fifth, in the era of industrial revolution 4.0, the technology gap is narrowed, leading to less and less product differentiation, the difference that businesses bring to customers lies in service, satisfying customers by service speed, service attitude and customer service. Therefore, Vietnamese startups need to pay attention to develop logistics systems and management to serve customers timely with no mistakes.

\section{Conclusion}

Thus, through practical research in 518 Vietnamese startups on the impact of business strategy and market orientation on operating results, both business strategy and market orientation components in all schools have positive impacts on the results 
of the startup businesses. However, a business strategy only affects the business performance positively, but the impact of its regulatory relationship on Vietnamese startups' performance has not been found. In addition, market-oriented components also have positive impacts on the performance of Vietnamese start-ups in the order from highest customer orientation to competitor orientation and lowest orientation of cross-functional collaboration. Thereby, the study has proposed 05 suggestions for solutions to guide the success of Vietnamese startups in the coming years.

\section{Acknowledgement}

The authors would like to thank the anonymous referees for constructive comments on earlier version of this paper.

\section{References}

Beard, D. W., \& Dess, G. G. (1981). Corporate-level strategy, business-level strategy, and firm performance. Academy of management Journal, 24(4), 663-688.

Chung, Y. C., Hsu, Y. W., Tsai, S. C., Huang, H. L., \& Tsai, C. H. (2012). The correlation between business strategy, information technology, organisational culture, implementation of CRM, and business performance in a high-tech industry. South African Journal of Industrial Engineering, 23(2), 1-15.

Day, G. S. (1994). The capabilities of market-driven organizations. Journal of Marketing, 58(4), $37-52$.

Dina, N., \& Cahyandito, M. F. (2018). The Analysis of Market Orientation and Company Resources in the Business Strategy Preparation for Performance Improvement of Automotive Lubricant's Companies in Indonesia. Academy of Strategic Management Journal, 17(6), 1-14.

Gonçalves Filho, C., Veit, M. R., Souki, G. Q., Monteiro, P. R. R., \& Neto, M. T. R. (2012). Strategy, market orientation and entrepreneurship: proposition and test of rival business performance prediction models. International Journal of Entrepreneurship and Innovation Management, 15(4), 275-291.

Gaur, S. S., Vasudevan, H., \& Gaur, A. S. (2011). Market orientation and manufacturing performance of Indian SMEs. European Journal of Marketing, 45(7/8), 1172-1193.

Ho, K. L. P., Nguyen, C. N., Adhikari, R., Miles, M. P., \& Bonney, L. (2018). Exploring market orientation, innovation, and financial performance in agricultural value chains in emerging economies. Journal of Innovation \& Knowledge, 3(3), 154163.

Kohli, A. K., \& Jaworski, B. J. (1990). Market orientation: the construct, research propositions, and managerial implications. Journal of Marketing, 54(2), 1-18.

Menguc, B., \& Auh, S. (2008). The asymmetric moderating role of market orientation on the ambidexterity-firm performance relationship for prospectors and defenders. Industrial Marketing Management, 37(4), 455-470.

Miles, R. E., Snow, C. C., Meyer, A. D., \& Coleman Jr, H. J. (1978). Organizational strategy, structure, and process. Academy of Management Review, 3(3), 546-562.

Van Raaij, E. M., \& Stoelhorst, J. W. (2008). The implementation of a market orientation. European Journal of Marketing, 42(11/12), 1265-1293.

Raymond, L., \& Croteau, A. M. (2008). Manufacturing strategy and business strategy in medium-sized enterprises: performance effects of strategic alignment. IEEE Transactions on Engineering Management, 56(2), 192-202.

Slater, S. F., \& Narver, J. C. (1995). Market orientation and the learning organization. Journal of Marketing, 59(3), 63-74.

Williams, F. P., D'Souza, D. E., Rosenfeldt, M. E., \& Kassaee, M. (1995). Manufacturing strategy, business strategy and firm performance in a mature industry. Journal of operations management, 13(1), 19-33. 
(C) 2021 by the authors; licensee Growing Science, Canada. This is an open access article distributed under the terms and conditions of the Creative Commons Attribution (CC-BY) license (http://creativecommons.org/licenses/by/4.0/). 